\title{
Effect of Insurgency on Cattle Markets in Northeast Nigeria: Appraisal of Kasuwan Shanu Cattle Market, Maiduguri, Borno State
}

\author{
Hassan Mohammed ${ }^{*}$, Funmilola F. Ahmed, Abdulkabir N. Adedeji \\ Department of Economics, Faculty of Social Sciences, University of Maiduguri, Maiduguri, Nigeria \\ Email address: \\ hassanmiringa83@gmail.com (H. Mohammed) \\ ${ }^{*}$ Corresponding author
}

\section{To cite this article:}

Hassan Mohammed, Funmilola F. Ahmed, Abdulkabir N. Adedeji. Effect of Insurgency on Cattle Markets in Northeast Nigeria: Appraisal of Kasuwan Shanu Cattle Market, Maiduguri, Borno State. Science Research. Vol. 8, No. 5, 2020, pp. 108-114. doi: 10.11648/j.sr.20200805.11

Received: February 13, 2020; Accepted: April 13, 2020; Published: September 14, 2020

\begin{abstract}
The decade attacks of Boko Haram insurgent has left many people displaced and destroyed many lives and properties in the Northeast Nigeria. However, little attention is paid to the degree at which this conflict has affected influential business activities especially cattle supply. The study examined the effect of Boko Haram insurgency on cattle marketers in Kasuwan Shanu, Maiduguri, Borno State. A structured questionnaire was designed to gather primary data from selected cattle marketers. Descriptive statistics and business budget model were used for data analysis. Furthermore, percentage change of employment generated by cattle marketing dropped by $100 \%$ from $2009-2014$. The result showed that, before insurgency $81 \%$ of the cattle traders earned above $\$ 80,000.00$ as income per month, while about $57 \%$ earned less than $\$ 80,000$ during insurgency per month in study area. The result revealed that cattle supply is drastically reduced by almost $96 \%$ during insurgency. More so, the net profit per head of cattle during the insurgency was about $\$ 29,500$, dropped from $\$ 51,200$ before the insurgency. As the condition is currently perceived to be enabling and conducive in the state, there is need for concerted effort to be made by all the stakeholders in revamping the cattle business to return and spin-off the economy of the state.
\end{abstract}

Keywords: Boko Haram Insurgency, Conflict, Business Activities, Cattle Supply, Economy

\section{Introduction}

The decade attacks of Boko Haram insurgent has left many people displaced and destroyed many lives and properties in the Northeast Nigeria, and many business activities in the region were crumbled especially cattle business. Nigeria is one largest cattle producer in Sub-Saharan Africa, apart from crude oil, and largest market for cattle in the Northeast. The record shown that the country has over 14.73 million cattle which are used for food (milk and beef) and other intermediate materials in craft industries. More importantly, cattle business contributes about $12.7 \%$ to agricultural gross domestic production Nigeria [7] and contributes about N135.4 billion to GDP [13].

According to the National Livestock Project Division [20], the supply of cattle and its products has witnessed a decline while its demand has been increasing with the result being a shortfall in the supply. Owing to the considerable spatial separation of production area from consumption area and other ancillary factors, there is high handling cost especially in relation to cattle transportation [10]. Marketing, therefore, encompasses all business activities associated with the transfer of a product from the producers to the consumers [12]. The cattle marketing process makes possible the delivery of cattle to the buyers in the form, place and time needed. This process of bringing the cattle from where there are surpluses (production) to where there are shortages (consumption), a process known as arbitraging, needs to be fully understood to enhance the efficient working of cattle markets, which is vitally important in achieving sustainable and profitable agricultural commercialization in the livestock sub-sector in Nigeria [14, 15]. Marketing is an economic activity which stimulates further production and if efficiently done, both the producer and consumer get satisfied in the sense that the former gets a sufficiently remunerative price for the product to continue to produce, while the latter gets it 
at an affordable price that stimulates continued consumption [15].

Nigeria is one of largest market for cattle in West Africa and has great potential to increase her cattle production. The cattle trading activities in cattle market (Kasuwanshanu) in Jere Local Government Area of Borno state is a lucrative economic activity that provides substantial livelihoods and employments to many cattle traders in the area. This has once created increased cross-border trade between Borno, Niger, Chad, and Cameroon. Borno experienced multiple and severe attacks of Boko Haram insurgency which appear to have unmeasurably affected cattle production and supply in the area. It has been recorded that the insurgent attacks that last for almost a decade led to increase in cattle rustling and killing and displacement of herders which creates disruption in supply, distribution and high prices of cattle and causes displacement of cattle marketers [1]. This compounds challenges facing cattle production in Northeast Nigeria. According to [21] and [2], Boko Haram insurgency attacks has more adverse effects on economic and social development in the afflicted-areas than some ancillary aspects which many studies had focused (see [27]). The repercussion of the dreadful attacks perpetrated by this insurgent in Maiduguri, Borno State, has caused major economic problem and adversely affects cattle market.

Despite the established facts that there is high demand for cattle and its products, and the supply is hampered, however, the extent the effect of Boko Haram insurgency on the supply of cattle in Kasuwanshanu has not only adequately appraised, but opens a serious concern. This leads this study to ask: what degree has insurgency affected supply of cattle, the income of the cattle traders?; and what extent has repercussion of insurgent attacks regressed cattle supply chain and employment in cattle business? These questions draw the attention of this present work to assess the effect of Boko Haram insurgency on cattle marketers in Kasuwanshanu.

\section{Literature Review}

As market access is often affected by road blockages and numerous checkpoints, maintaining adequate supplies of cattle is one of the major challenges facing cattle traders. In Jere local government area, Borno State. The market supply of imported cattle is slightly more stable than the supply of local cattle despite the impact of the depreciation in the value of the Nigerian Naira on the cost of imports. Borno State, on the international front is bordered by three countries namely: Niger, Chad and Cameroon. These countries constitute major trading partner to the State in particular and Nigeria in general. Substantial amount of the State's cattle requirement comes from Chad and Cameroon. Borno State also provides ready market for her neighbouring countries in terms of agricultural produce such as cattle and its products. Thus, there is a buoyant cross-border trade between the State and her international neighbours [6]. The State has 27 local government areas and most of its northern Local Government
Areas (LGA) trades their cattle in Kasuwanshanu, Maiduguri.

However, there exists a reasonable amount of cattle inflow from neighbouring countries such as Cameroun, Chad and Niger. The Nomadic nature of rearing cattle makes the estimation of its population difficult. These movements involve the crossing of borders, particularly between Chad and Nigeria. This long trans-border movement forces most of the cattle to thrive at a subsistence level and more energy and vitality that would have been used for production purposes is now wasted in moving. The high level of cattle production in the zone is made possible by the favourable ecological features such as accessible drinking water of Lake Chad, River Benue and its tributaries, as well as free-abundant natural pasture along Gamboru Ngala-Marte plains, among others in the state [14].

Cattle make multiple contributions to the economic and social wellbeing of people in the developing world, providing highly nutritious foods, an income stream, assets against which to borrow, the primary source of organic fertilizer, energy for cultivation or transport, and a host of other social functions [19]. Cattle are a key asset in mitigating risk, especially in pastoral areas. In 2010 there were 752 million livestock keepers living on less than USD 2 per day [22], so increasing cattle productivity and resilience provide a unique opportunity to lift people out of poverty. Investing in women's ability to raise cattle has significant livelihood potential, not least because women are far more likely to own cattle than land. Many more people derive indirect benefits from cattle though, for example, trading, input supply, marketing and processing-and their incomes could also rise if the sector were to become more productive, creating additional jobs and business opportunities throughout the sector.

Cattle producers are uncertain about when they can safely access markets due to attacks on cattle market. Cattle marketers have largely ceased or downscaled activities due to insurgency, and market actors face a number of constraints. These include limitations in the supply of, and access to cattle markets, an increase in taxation and fees, a decrease in the number of traders and producers and a general reduction in the consumption of cattle and its products due to economic constraints at the household level.

Cattle constitutes a major contributor to the economy and livelihoods of large population in the study area, with more than $75 \%$ of daily food subsistence drawn directly or indirectly from cattle and its products. But, with the emergence of Boko Haram insurgency, cattle traders faced enormous security challenges in bringing their products to the market. Boko Haram often attacked their flocks and collected their money. Thus, many of them were either forced to limit their activities or quit cattle marketing altogether and forced people who depend on selling cattle for their livelihoods to find other sources of living. Moreover, the Boko Haram insurgents declared brokering and taxing herdermen illegal, further disrupting the marketing of cattle. From the foregoing, it is obvious why cattle production and 
marketing are considered as notable employment and income-generating livelihood activities for a significant proportion of Nigerians [7, 25].

Growing insurgency in the study area has seriously affected the livelihoods of cattle marketers such that many people including businessmen are fleeing to more peaceful environment in other parts of the country. More so, the prices of cattle products have been increasing astronomically following the drastic fall in the supply of the cattle from Jere cattle market to the other parts of Nigeria where they are greatly consumed [1].

Reference [11] in his view on the negative impact of Boko Haram insurgency on the economy opined that "there can be no real progress made in any country that is suffering from insurgency" [5], assert that Boko Haram insurgency has not only led to closure or abandonment of peoples business activities within the affected region but also led to immigration of people from the affected region as well as led to reduction of patronage of products from northern region because of rumour that Boko Haram strategists are planning to send poisonous products to other parts of the country.

Socio-economic activities particularly in Kasuwanshanu, and Borno state in general, since 2009 has witnessed considerable decline as people and properties have been subjected to attacks by the insurgents. Boko Haram have killed many people and destroyed properties worth over a billion dollars. Building destroyed, properties destroyed / stolen, and livelihoods of many households affected forcing hundreds of business to close or relocate. The concentration of this sect in the Northern part of Nigeria that is noted for agricultural activities poses a threat to food security in the region and Nigeria in general [24].

Reference [12] revealed that the effect of Boko Haram insurgency on gross margin/profit for the cattle marketers was still increasing but at a decreasing rate even after the insurgency. This implies that the insurgency has impact on the profitability of the cattle marketing though total variable cost increased during the insurgency. Marketers therefore earned higher profit than during the insurgency.

\section{Methodology}

The information used for this study was collected from both primary and secondary sources. Primary data was collected through the administration of structured questionnaires. The questionnaire was designed to capture variables specified: cattle prices before and after insurgency, income of the marketers, employment, costs and profitability.
The population frame of the respondents was obtained from the cattle market association form which the sample size was selected. The questionnaire was self-administered with the help of some cattle marketers in the study area.

\section{Sampling technique and method}

Kasuwan Shanu in Jere LGA was purposively selected for this study based on the high cattle trading and concentration of cattle marketers in this market. The market is semiorganized as a cattle marketers association in the market that comprises wholesalers (producers or cattle fatteners), retailers and brokers that registered under the association. The registered members of 225 were obtained from the association and non-probability method, convenience sampling, was employed to select 125 respondents (60 wholesalers, 35 retailers and 30 brokers). However, out of the 125 questionnaire administered, 15 were inappropriately completed. As a result, only 110 questionnaire were used for analysis. We chose these marketers as respondents considered the fact that they are appropriate in the market to be to address all of the questions and have a holistic understanding and have experience of the insurgent attacks of trading activities and livelihoods of the traders and those of employment, costs and socio-economic characteristics information.

Descriptive statistics were used to examine the socioeconomic characteristics and livelihood of cattle marketers. This method has been applied in many studies e.g. [8, 26, 3, $19,18]$, on cattle marketing. To further the investigation, simple business budget model, adopted from and [9], first used by [4], was employed to determine the profitability of cattle transactions. The model is expressed as follows:

$$
\mathrm{NP}=\mathrm{TR}-\mathrm{TC}
$$

Where NP is net profit, TR denotes total revenue and TC is total cost incurred in buying cattle. The main costs considered include cost of transportation, cost of loading and off-loading of cattle, cost of feeding, association fees, commissions, and taxes paid to the government per transaction.

\section{Data Presentation and Results}

The effect of insurgency on the cattle market was captured from the trend of business before and during the insurgency. The study revealed that cattle supply has been drastically reduced during insurgency by 4,875 as presented in Table 1 .

Table 1. Weekly Cattle Supply to Kasuwan Shanu.

\begin{tabular}{lllllll}
\hline Period & No. of vehicle & $\begin{array}{l}\text { No. of cattle } \\
\text { Per vehicle }\end{array}$ & $\begin{array}{l}\text { Total supply of } \\
\text { cattle by vehicle }\end{array}$ & $\begin{array}{l}\text { Foreign supply } \\
\text { By foot }\end{array}$ & $\begin{array}{l}\text { Local supply } \\
\text { by foot }\end{array}$ & $\begin{array}{l}\text { Total supply } \\
\text { Percentage (\%) }\end{array}$ \\
\hline Before & 60 & 5 & 300 & 4,000 & 800 & 5,100 \\
During & 15 & 5 & 75 & - & 150 & 225 \\
Differences & 45 & - & 225 & - & 650 & 4 \\
\hline
\end{tabular}

Source: Field Survey, 2016.

The flow of cattle to and from Borno was greatly hampered by insurgency in the Jere cattle market. Following 
the insurgency, trade from local producers was disrupted, as many animals had been lost, while the other herdsmen migrated. Furthermore, Kasuwanshanu has been severely disrupted; the cases of theft and cattle rustling were highly increased in the market during the period. This implies that there is a reduction in income and ultimately affected the consumption pattern of the marketers.

The cost prices of cattle have risen. Table 2 highlights the prices of different categories of cattle before and during the insurgency. The cost of doing the business has increased due to the increase in checkpoints, and the informal and formal fees charged at each of the checkpoints. Hence, the number of animals into the market has reduced-as well as the number of animals being moved out of the market. It shows that traders were paying more for cattle due to fall in supply but increase in the costs of getting animals to points of sale.

Table 2. Cost price of Cattle before and after insurgency.

\begin{tabular}{lllll}
\hline Cattle size & Before (\#) & After ( $¥)$ & Differences (\#) & \% change \\
\hline Larger & 145,000 & 180,000 & 35,000 & 24 \\
Medium & 80,000 & 135,000 & 55,000 & 69 \\
Small & 25,000 & 40,000 & 15,000 & 60 \\
\hline
\end{tabular}

Source: Field Survey, 2016

Also, fall in cattle supply may be traced to displacement of herders by insurgents which now become difficult to revamp the market. Though the forces of demand and supply could determine the market price of cattle, however, the precarious effect of Boko Haram in the study area has effect on supply that significantly affects the price. Also, the supply might reduce owing to increase of many road blocks by security personnel which ultimately increased the cost of transportation and risk of transporting cattle into the market. Putting together, one may deduce that increase in cost price of cattle resulting from the insurgence attacks drastically hampered supply of cattle in Kasuwanshanu.

The cost items of cattle business are presented in Table 3 below. There was no fixed cost item because traders did not own either a ware house or a truck. Most of their expenses were restricted to the operational costs of maintaining the animals in terms of supplementary feedings before final conveyance to the distant markets as well as taxes/levies paid in transit and thus profit could be calculated.

Table 3. Average cost of cattle per head.

\begin{tabular}{llll}
\hline Item & Before (N) & After (A) & Differences (A) \\
\hline Average cost of cattle & 80,000 & 135,000 & 55,000 \\
Levies & 100 & 100 & - \\
Transportation & 300 & 1000 & 7,000 \\
Loading/off-loading & 300 & 300 & - \\
Feeding & 500 & 1000 & 500 \\
Commission & 2500 & 3000 & 500 \\
Association fee & 100 & 100 & - \\
Security fee & - & 100 & 100 \\
\hline
\end{tabular}

Source: Field Survey, 2016
Results in Table 3 revealed that fixed cost per head of cattle before and during the insurgency was N80,000 and N135,000 respectively. This cost may vary depending on the time of marketing, type (either male or female), breed, location of market, body build-up of the animal, etc. The transportation cost per head also varies depending with the mode of transportation from the source of the suppliers. This could either be by trekking or by vehicles. The cost of transportation locally attracted about $\$ 300$ per head before insurgency and for the same distance attracted 1000 during insurgency per head of cattle. The study further showed that for each head of cattle brought to the market, the official levy is $\$ 100$ and loading/off loading ( $\$ 300$ ) are the only variables that have not changed in cattle trade in the study area. The Local Government Authority is paid the same fee ( 1100 ) before and during insurgency. The cost is normally part of the internally generated revenue efforts of the Local Government to complement the central government monthly allocation. Similarly, these monies are used for providing basic social and infrastructural services such as market maintenance; provide security for the marketers and the animals in the local government area.

Commission on any sale per animal attracts $\$ 2,500-$ $\$ 3,000$ and this amount is neither fixed nor remittable to the government account, but rather a settlement between operators to settle witnesses and bargainers during the marketing process. The payment of the commission may also be based on understanding relationship between the parties involved. These imply that general increases in the cost of marketing per head of cattle during the insurgency led to the reduction of revenue generated.

Table 4. Effects of Insurgency on cattle traders' income.

\begin{tabular}{lllll}
\hline Before insurgency During insurgency (2009-2015) & & & Frequency & Percentage \\
\hline Household income & Frequency & Percentage & 30 & 27 \\
\hline Less than $N 40,000$ & 8 & 7 & 18 & 16 \\
N40,000-79,999 & 13 & 35 & 23 & 21 \\
N80,000-119,999 & 38 & 24 & 25 & 23 \\
N120,000-159,999 & 27 & 13 & 4 & 9 \\
Above N200,000 & 14 & 9 & 10 & 100 \\
TOTAL & 10 & 100 & 110 & \\
\hline
\end{tabular}

Source: Field Survey, 2016 
Results shown in Table 4 revealed that before insurgency, the average income for traders ranged from $\$ 100,000$ per month among the surveyed households. However, insurgency has had a negative impact on all income sources, especially incomes from the sale of crops and cattle. Households indeed reported a drastic drop in monthly incomes from the different sources.

The result showed that before insurgency majority of the cattle marketers earned higher income than during the insurgency. Majority (81\%) of the respondents earned $\$ 80$, 000.00 and above before insurgency. However, during insurgency only $57 \%$ earned N80, 000.00 and above monthly income. This implies that as cattle marketing chain is disrupted by insurgency, the resultant effect is fall in volume of sales of cattle and consequently household incomes. The ability of rural cattle producers to raise their incomes also depends on their ability to compete in the market effectively [17]. This consequently will create some level of hardship and decreased the standard of living in households

Since the insurgency, additional income earning opportunities have been limited; indirectly disrupting livelihoods of cattle marketers and the community as a whole. It was concluded that insurgency has affected the economic condition of household income up to $25 \%$ [28].

The cattle business is also directly responsible for a substantial amount of employment, with many of the jobs located in Kasuwan shanu. Nevertheless, Table 4 provides some perspective on trends of employment in cattle business, and makes evident the significant reduction in employment associated with the onset of insurgency conditions in 20092015.

Table 5. Effect of insurgency on employment generation.

\begin{tabular}{llll}
\hline Activities & $\begin{array}{l}\text { Before } \\
\text { insurgency }\end{array}$ & $\begin{array}{l}\text { During } \\
\text { insurgency }\end{array}$ & Difference \\
\hline Producer/wholesalers & 100 & 65 & 40 \\
Retailers & 75 & 30 & 40 \\
Brokers & 50 & 30 & 20 \\
Total & 225 & 125 & 100 \\
\hline
\end{tabular}

Source: secondary data

Results shown in Table 5 revealed that percentage change of the employment generated by cattle traders decreased by $100 \%$, while the total employment generated was estimated to be 225 persons daily while during insurgency cattle marketing involve only 125 persons. This implies that insurgency plays a great role in affecting employment generating activities for cattle marketers/traders because the difference before and during insurgency of 100 persons. This result supports the assertion of [23], that cattle production and trading are notable employment and income-generating livelihood activities for many Nigerians. Notably, the market is often characterized by youths involved in some form of business which generate income alongside with income accruing from cattle sales. Insurgency has indeed disrupted these activities and rendered many household members unemployed.
The profit is obtained by deduction the cost of business from total revenue. The characteristics of cattle and the business function that must be performed as the cattle passes through the marketing system affect the profit of the marketers.

Table 6. Profit Generation before insurgency.

\begin{tabular}{|c|c|c|c|c|}
\hline Item & $\begin{array}{l}\text { Quantity } \\
\text { Per Week }\end{array}$ & $\begin{array}{l}\text { Unit Price } \\
\text { (\#) }\end{array}$ & $\begin{array}{l}\text { Total } \\
\text { Price (N) }\end{array}$ & Net Profit \\
\hline $\begin{array}{l}\text { Number of cattle } \\
\text { Variables cost: }\end{array}$ & 35 & 80,000 & $2,800,000$ & \\
\hline $\begin{array}{l}\text { Government Levies } \\
\text { Transport } \\
\text { Loading/offloading } \\
\text { Feeding } \\
\text { Commission } \\
\text { Association fee }\end{array}$ & & $\begin{array}{l}100 \\
300 \\
300 \\
500 \\
2500 \\
100\end{array}$ & $\begin{array}{l}3500 \\
10,500 \\
10,500 \\
17,500 \\
87,500 \\
3500 \\
133,000\end{array}$ & \\
\hline Total Cost & & & $2,933,000$ & \\
\hline $\begin{array}{l}\text { Selling Price/head } \\
\text { Total Revenue }\end{array}$ & 35 & 135,000 & $4,725,000$ & \\
\hline $\begin{array}{l}\text { Profit } \\
\text { Profit per head }\end{array}$ & & & & $\begin{array}{l}1,792,000 \\
51,200\end{array}$ \\
\hline
\end{tabular}

Source: Secondary data

From the analysis in Table 6 it was revealed that the total revenue generated before insurgency was about $\$ 4,725,000.00$ with profit of $\$ 1,792,000.00$. This gives a profit of $¥ 51,200$ per head of cattle to the cattle traders and the average cost price per head of cattle was $\$ 135,000.00$ and it show that a cattle business is a profitable venture in the study area. The findings were in line with [17]. who's result of profitability analysis showed that cattle business as profitable venture in the southwest part of Nigeria.

The profit is obtained by deduction the cost of business from total revenue. The characteristics of cattle and the cost of business affect the profit level of the marketers.

Table 7. Profit Generation After insurgency.

\begin{tabular}{|c|c|c|c|c|}
\hline Item & Quantity & $\begin{array}{l}\text { Unit } \\
\text { price (N) }\end{array}$ & $\begin{array}{l}\text { Total price } \\
\text { (A) }\end{array}$ & $\begin{array}{l}\text { Net- } \\
\text { Profit }\end{array}$ \\
\hline $\begin{array}{l}\text { Number of cattle } \\
\text { Variables cost: }\end{array}$ & 16 & 145,000 & $2,320,000$ & \\
\hline $\begin{array}{l}\text { Levies } \\
\text { Transport } \\
\text { Loading/off loading } \\
\text { Feeding } \\
\text { Commission } \\
\text { Association fee }\end{array}$ & & $\begin{array}{l}100 \\
1000 \\
300 \\
1000 \\
3000 \\
100\end{array}$ & $\begin{array}{l}1,600 \\
16,000 \\
4,800 \\
16,000 \\
48,000 \\
1,600 \\
88,000\end{array}$ & \\
\hline $\begin{array}{l}\text { Total Cost } \\
\text { Selling Price/head } \\
\text { Total Revenue } \\
\text { Profit } \\
\text { Profit per head }\end{array}$ & 16 & 180,000 & $\begin{array}{l}2,408,000 \\
2,880,000\end{array}$ & $\begin{array}{l}472,000 \\
29,500\end{array}$ \\
\hline
\end{tabular}

Source: Secondary data

Results shown in Table 7 revealed that, the total revenue generated during the insurgency was about $\$ 2,880,000.00$ with net revenue of 472,000 . This gives net revenue of $\$ 29,500$ per head of cattle to the cattle traders and it shows 
that a cattle marketing is still a profitable venture in the study area. The findings were in line with [17]. who's result of profitability analysis showed that cattle business as profitable venture in the southwest part of Nigeria.

Table 8. Effect of Insurgency on Revenue Generation to Jere Cattle Marketers.

\begin{tabular}{lllll}
\hline Item & Quantity FC & TVC & TR & Profit \\
\hline Before & $352,800,000$ & 133,000 & $4,725,000$ & $1,792,000$ \\
After & $162,320,000$ & 88,000 & $2,880,000$ & 472,000 \\
Differences & 19480,000 & 45,000 & $1,845,000$ & $1,320,000$ \\
\hline
\end{tabular}

Source: Secondary data

Results shown in Table 8: summarized the difference between the fixed cost, total variable cost and total revenue and the total profit before and during insurgency as $\$ 480,000, \quad \$ 45,000, \quad \$ 1,845,000$ and $\$ 1,320,000$ respectively. Marketers can still make profits from the business, that is, from $\$ 1,792,000$ to $\$ 472,000$ though at a reduced rate. Before the insurgency, cattle marketers earned an average of 51,200 per cattle and during insurgency; they earned an average of 29,500 . The findings were in line with the findings of [19] which indicated that insurgency has increased the cost of marketing and reduced the level of profit earned.

\section{Conclusion}

The study concluded that the effect of Boko Haram insurgency has drastically decreased cattle market activities due to closures the borders, unnecessary checkpoints, and illegal taxations of cattle. Cattle price, ultimately increased, hence low income earned by respondents.

Though cattle's marketing is profitable venture in the study area with potential for employment and income generation, households are faced with increased deficit in their ability to purchase cattle due to the combined impact of reduced production, limited cattle supply and consequent reduced income.

Based on the findings of the study, the following recommendations were preferred:

Concerted effort is needed from all stakeholders to arrest the deplorable security situation in the country to enable marketers have conducive environment to carry their transactions thereby reducing the unnecessary checking point, robbery, banditry, theft and then opening of the borders to increase cattle marketing activities.

Since cattle trade is a profitable venture in the study area, government could encourage marketers to venture into the business by providing soft loans to stabilize old marketers and also encourage new entrants into the cattle market. This is a policy option for combating the endemic menace of unemployment. Government should also develop cattle ranch and encourage cattle fatting. This will increase cattle supply to the study area.

Government should accord priority to road construction and rehabilitation to help improve the challenge of poor road infrastructure. Government should also rigorously pursue resuscitation of the moribund rail transportation system to provide a cheap and reliable means of transportation to marketers and their merchandise.

\section{References}

[1] Abigail J. J. (2014). The Impact of Conflict and Political Instability on Agricultural Investments in Mali and Nigeria. African Growth Initiative at Brookings. Working Paper17 July, 2014. Pp 14-16.

[2] Adetiloye T. (2014). The Root Causes of Boko Haram and Insurgent Groups in Nigeria- Sahara reporters.

[3] Aminu, D. (2012). Revenue Allocation, underdevelopment and insecurity: Need for Re-examination. Gidauniya investment and securities LTD. Pp 1-4.

[4] Akinbuwa. O. S. (1995). The Role of Licenced Buying Agents (LBA) in the Marketing of Cocoa in Akure South Local Government Area of Ondo State Applied Tropical Agriculture, 10 (2): 23-29.

[5] Aro, O. I. (2013). Boko Haram Insurgency in Nigeria: It and way forward toward future insurgency. International Journal of Scientific and Research Publications, 3 (11): 1-8.

[6] Balami, D. H. (2006). "Trans-border Trade-Effects on the Economy of Borno State" A paper at the Borno Economic Submit, Musa Usman Secretariat, 7 May.

[7] Central Bank of Nigeria (1999). Statistical Bulletin and Annual Report and Statement of Accounts. Various issues. Pp 123-136.

[8] Esenu B. N. (2005). Gender Relations in livestock Production and for household food security in the Teso Farming System (TFS): Pp 26-31.

[9] Folayan, J. A/ Oguntade, A. E. and Ogunderi, K. (2007). Analysis of Profitability and Operational, Cocoa Marketing: Empirical Evidence from Nigeria. Journal of social science, 15 (2): 197-199.

[10] Filani, M. O. (2006). Transport Market Study- The Bodija Cattle Market in Ibadan. Department of Geography University of Ibadan, Nigeria. P113.

[11] Isakpa, P. (2011 August 29). Bomb Blast, Boko Haram and Democrats at the gate. Business Day, (9): 159-200.

[12] Jones, S. (1996). Food markets in Developing countries: what do we know? Food studies Group working paper No. 8 Oxford. Pp 123-135.

[13] Kohls, R. L. and Uhls, J. N. (1985). Marketing of Agricultural Products. Sixth Edition, McMillan Publishers Company, New York. Pp 5-8.

[14] Lawan. O. M., Mustapha. B. A and Malah. B. (2016). Factors Influencing Informal Cross Border Cattle Trade between Chad and Nigeria. Journal of Humanities and Social Science (IOSRJHSS) 21 (2): 07-12.

[15] Mafimisebi, T. E. (2011). Spatial Price Equilibrium and Fish Market Integration in Nigeria: Pricing Contacts of Spatially Separated Markets. LAP Lambert Publishing Company, Germany. P157. 
[16] Mafimisebi, T. E. (2012). Spatial Equilibrium, Market Integration and Price Exogeneity in Dry Fish Marketing in Nigeria: A Vector Auto-regressive (VAR) Approach. Journal of Economics, Finance and Administrative Sciences, 17 (33): 31-37.

[17] Mafimisebi, T. E., Mafimisebi, O. E. and Ikuemonisan, E. S. (2013). The Informal Market for Medicinal Herbs and Herbal Medicine as a Supplementary Income Source for Women in Ondo State, Niger ia. A book Chapter in Miracles of EthnoBotany (Socio Economic Aspects). Pp 83-113.

[18] Mohammed, M. Y. and Mohammed A. (2015). "The Emergency Market Mapping Analysis" mercy corps southern Sudan. Pp 9-15.

[19] Mubi A. A; Michika S. A and Midau. A (2013). Cattle Marketing in Mubi Area of Adamawa State, Nigeria. Agriculture and Biological Journal of North America. 3 (4): 199-198.

[20] Nigerian National Livestock Project Division (1992): NLPD Survey in Kaduna, Nigeria, Vol. 58: 175-177.

[21] Obioma, L. (2002). Conflict Management Ikeja-Lagos: Thomas Nelson Nig. Ltd. P92.

[22] Otte, M. J. \& Chilonda, P. J. (2012)."Cattle and Small Ruminant Production Systems in Sub-Saharan Afirican. A Systematic Approach”. FOA P187.
[23] Okunmadewa F. Y. and Mafimisebi, T. E. (2006). Are Middlemen Really Exploitative? Empirical Evidence from the Sundried Fish Market in Southwest, Nigeria. In: Rebuilding Fisheries in an Uncertain Environment, CDROM of Biennial Conference of the International Institute of Fisheries Economics and Trade. Pp I2.

[24] Paul, O., Andrew, J., Olugbode, M. \& Chucks, O. (2013). "outrage as Gunmen kill 40 students in Yobe" Thisday September 29 (5).

[25] Tibi, K. N. and Aphunu A. (2010). Analysis of Cattle Market in Delta State: The Supply Determinants. African Journal of General Agriculture. 6 (4): 199-203.

[26] Tijjani. A., Ala. A. L, Maikasuwa M. A, and Ganawa N. (2011). Economic Analysis of Breeding in Chibok Local Government Area of Borno State. Nigeria Journal of Basic and Applied Science. 19 (2): 285-292.

[27] Tukur, M. D. and Ahmed F. F. (2015). The Effect of Insurgency on Borno State Economy (2008-Oct. 2014). Journal of Economics and Sustainable Development. 6 (16): 95-97.

[28] World Bank. 2013. Poverty and Equity Brief: Sub-Sahara Africa, Nigeria, April, 2013. Washington, DC: World Bank. 